\title{
PENGEMBANGAN MEDIA PEMBELAJARAN E-KOMIK PADA MATERI DINAMIKA ROTASI
}

\author{
Henny Purnamasari ${ }^{1, \text { a) }}$, Siswoyo ${ }^{1, b)}$, Vina Serevina ${ }^{1, c)}$ \\ ${ }^{1}$ Prodi Pendidikan Fisika, Fakultas Matematika dan Ilmu Pengetahuan Alam, Universitas Negeri Jakarta, Jl. \\ Rawamangun Muka No. 1, Jakarta Timur 13220
}

Email: ${ }^{\text {a) }}$ hennypurnama23@gmail.com, ${ }^{\text {b) }}$ siswoyo@unj.ac.id, ${ }^{\text {c) }}$ vina.serevina77@gmail.com

\begin{abstract}
Abstrak
Penelitian ini bertujuan mengembangkan media pembelajaran komik elektronik (e-komik) yang layak digunakan untuk mendukung proses pembelajaran. Media pembelajaran adalah alat yang digunakan dalam proses belajar mengajar untuk mengantarkan informasi supaya tujuan pembelajaran mudah tercapai. E-komik materi dinamika rotasi merupakan suatu seni visual terdiri atas susunan gambar yang bercerita menyampaikan materi dinamika rotasi dan dirancang menggunakan teknologi modern sehingga bisa ditransfer ke berbagai media penyimpanan dan berekstensikan .apk. Metode penelitian ini menggunakan model ADDIE yang meliputi lima tahapan, yaitu tahap analisis (Analyze), tahap perencanaan (Design), tahap pengembangan (Development), tahap impelementasi (Implement), dan tahap evaluasi (Evaluate). Hasil validasi dan uji coba menunjukkan rata-rata persentase oleh ahli materi $83.00 \%$, oleh ahli media $78.11 \%$, oleh ahli bahasa $82.22 \%$, oleh guru fisika SMA $86.18 \%$, dan dari peserta didik SMA kelas XI 83.96\%. Hasil rata-rata uji gain sebesar 0.40 menunjukkan bahwa peningkatan pemahaman peserta didik termasuk dalam interpretasi sedang. Sehingga, media e-komik materi dinamika rotasi ini layak digunakan sebagai media pembelajaran.
\end{abstract}

Kata-kata kunci: pengembangan, e-komik, dinamika rotasi

\begin{abstract}
This study aims to build electronic comic learning media (e-comic) that is used to support the learning process. Learning Media is a tool used in learning to deliver information. E-comic material of rotational dynamics is a visual art consisting of a composition of images that tell a different material and is designed using modern technology. Can be accessed to various storage media and extends .apk. This research method uses the ADDIE model which includes five stages, namely analyze phase, design phase, development phase, implementation phase, and evaluation phase. Validation and trial results produced an average percentage of $83.00 \%$ by material experts, $78.11 \%$ by media experts, $82.22 \%$ by linguists, $86.18 \%$ by high school physics teachers, and $83.96 \%$ by high school students of class XI. The average profit result of 0.40 indicates that enhancement of learners' understanding is included in reasonable interpretation. Furthermore, the e-comic rotational dynamics is suitable for use as a learning medium.
\end{abstract}

Keywords: development, e-comics, rotational dynamics

\section{PENDAHULUAN}

Salah satu materi dari pelajaran fisika yaitu materi dinamika rotasi dan keseimbangan benda tegar merupakan salah satu materi yang termasuk sulit menurut kebanyakan siswa. Dalam penyelesaian permasalahan konsep dinamika rotasi dan keseimbangan benda tegar harus mengaitkan konsep gaya yang ada pada hukum Newton, konsep kinematika gerak, dan juga konsep gerak melingkar [1].

Dari hasil analisis penguasaan materi soal Ujian Nasional (UN) oleh Badan Standar Nasional Pendidikan bahwa daya serap yang menggambarkan persentase jawaban benar siswa terhadap soal yang dikerjakan siswa SMA di Kota Jakarta Pusat untuk pelajaran fisika pada materi dinamika rotasi dan keseimbangan benda tegar yaitu 64.11 dan daya serap di provinsi dan nasional yaitu 62.90 dan 
65.24. Sedangkan untuk materi lain seperti gerak lurus, gerak melingkar, dan gerak parabola daya serap di kota, provinsi, dan nasional masing-masing 85.47, 86.45, dan 72.48 [2]. Hasil data tersebut menunjukkan penguasaan konsep siswa pada materi dinamika rotasi dan keseimbangan benda tegar masih perlu ditingkatkan.

Menurut Heinich dkk media pembelajaran merupakan batasan medium yang digunakan sebagai perantara yang mengantar informasi antara sumber dan penerima [3]. Sehingga televisi, foto, film, gambar, bahan-bahan cetak, rekaman audio, dan sejenisnya merupakan media komunikasi. Apabila media itu membawa informasi yang memiliki tujuan instruksional atau mengandung pengajaran, maka media tersebut disebut media pembelajaran. Namun, peserta didik sekarang lebih banyak menghabiskan waktunya untuk bermain ataupun membaca komik dibandingkan untuk belajar. Hal ini terlihat dari hasil kuesioner analisa kebutuhan yang diberikan kepada 90 siswa SMAN 77 Jakarta yaitu $71,11 \%$ siswa selalu menggunakan komputer atau smartphone untuk membaca komik sedangkan untuk belajar dan mengerjakan tugas hanya $68,89 \%$.

Komik atau kartun (cartoon) merupakan sebuah cerita yang bergambar yang tersusun dalam potongan-potongan [4]. Oleh sebab itu, komik memungkinkan suatu informasi dapat disampaikan secara efektif sekaligus meningkatkan motivasi membaca. Dari hasil observasi kelas oleh Eastman, siswa lebih tertarik mempelajari dan membaca konten sains yang disajikan dalam bentuk komik. Siswa yang tingkat membacanya tinggi mempelajari teks secara rinci, sementara siswa yang memiliki tingkat membaca rendah termotivasi untuk membaca teks komik tersebut [5].

Komik memiliki beberapa komponen sehingga tampilan komik bisa terlihat lebih menarik, yaitu karakter yang merupakan semua tokoh dalam komik, frame yang membatasi tiap adegan, balon kata yang merupakan ruang untuk menuliskan percakapan, narasi yang merupakan kalimat penjelas cerita, efek suara, dan latar belakang atau background yang menggambarkan suasana cerita [6]. Komik juga memiliki unsur-unsur intrisik yaitu unsur yang membangun karya itu sendiri. Adapun unsur intrisik dalam komik yaitu tema cerita, latar (setting) yang terdiri dari latar tempat, latar waktu, dan latar suasana, sudut pandang, alur cerita, tokoh, dan amanat dalam cerita [7].

Penggunaan kartun atau komik dalam pembelajaran juga mulai mendapatkan perhatian diantara pendidik karena dapat meningkatkan pemahaman dan ketertarikkan, meningkatkan motivasi untuk belajar, memperbaiki perilaku, meningkatkan produktivitas dan kreativitas, mengurangi stress dan kegelisahan, meningkatkan keaktifan partisipasi siswa dalam proses pembelajaran, dan dapat mengurangi kebosanan [8]. Dari penelitian Listiyani dan Widayati juga didapatkan hasil bahwa media komik dapat mendorong siswa untuk menambah rasa ingin tahu, wawasan, dan pengetahuan [9].

Berdasarkan uraian tersebut, maka penelitian ini akan membuat "Pengembangan Media Pembelajaran e-Komik Materi Dinamika Rotasi”. E-komik materi dinamika rotasi yang berekstensikan .apk dibuat dengan menggunakan perangkat lunak SAI dan Adobe Photoshop CS3. Dengan memanfaatkan pengembangan media e-komik ini diharapkan peserta didik lebih antusias belajar fisika karena dilakukan dengan cara yang menarik dan tidak monoton.

\section{METODE}

Metode penelitian yang dilakukan adalah metode penelitian pengembangan (Research and Development / R\&D) dengan menggunakan model ADDIE meliputi lima tahapan, yaitu tahap analisis (Analyze), tahap perencanaan (Design), tahap pengembangan (Development), tahap impelementasi (Implement), dan tahap evaluasi (Evaluate) [10].

Sebelum melakukan tahap analisis berupa analisis kebutuhan, dilakukan juga studi literatur untuk mengetahui perkembangan penelitian terkait yang sudah dilakukan sebelumnya mengenai pengembangan media pembelajaran visual [11], media pembelajaran elektronik [12-17], komik [1820], dan materi dinamika [21]. Tahap analisis (Analyze), dilakukan analisis kebutuhan terhadap 90 peserta didik SMAN 77 Jakarta menunjukkan bahwa 97.78\% peserta didik sering menggunakan komputer atau smartphone, $71.11 \%$ menggunakan komputer atau smartphone untuk membaca komik, dan yang pernah membaca dan memiliki e-komik fisika yaitu $13.33 \%$ dan $6.67 \%$. Analisis teknologi yaitu pembuatan komik elektronik menggunakan software Paint Tool SAI yang merupakan software untuk melukis 
berkualitas tinggi dan ringan, memberikan pengoperasian yang mudah dan stabil, memungkinkan beberapa dokumen dapat dibuka disaat bersamaan, kanvas dapat diperbesar dan diputar, berbagai alat gambar yang dapat disesuaikan, dan komposisi sangat akurat dengan saluran ARGB 16Bit [22]. Dari hasil studi literatur, hasil penelitian Hamidon penggunaan kartun atau komik dalam pembelajaran mulai mendapatkan perhatian diantara pendidik karena dapat meningkatkan pemahaman dan ketertarikkan, meningkatkan motivasi untuk belajar, meningkatkan produktivitas dan kreativitas, dapat mengurangi kebosanan, dan sebagainnya. Dari hasil analisis penguasaan materi soal Ujian Nasional (UN) oleh Badan Standar Nasional Pendidikan (2015) didapatkan hasil yang menunjukkan bahwa penguasaan konsep peserta didik pada materi dinamika rotasi dan kesetimbangan benda tegar masih perlu ditingkatkan.

Tahap perencanaan (Design), kegiatan yang dilakukan pada tahap perencanaan, yaitu: a) Menentukan materi fisika yang akan dijadikan cerita yaitu materi dinamika rotasi, b) Membuat cerita serta menentukan karakter dalam cerita, c) Menyusun skenario untuk menentukan alur ceritanya. Adapun alur yang digunakan adalah alur maju. Kemudian menyusun skenario yang sesuai dengan materi pelajaran fisika yaitu mengenai dinamika rotasi. Adapun jenis font yang digunakan dalam menuliskan teks dialog dan narasi dalam komik elektronik adalah Tekton Pro, dengan ukuran font yaitu 22 sampai 28. Pemilihan font Tekton Pro dikarenakan font tidak terlalu tebal ataupun tipis, dan bentuk huruf tampak jelas sehingga memudahkan dalam pembacaan teks komik.

Tahap pengembangan (Development) produk media e-komik, yaitu: a) Membuat storyboard yaitu draft atau perencanaan kasar sebelum membuat sketsa komik seperti pada gambar, b) Pengerjaan ilustrasi merealisasikan bentuk storyboard ke dalam bentuk komik sesungguhnya, c) Validasi yang dilakukan oleh ahli media, ahli materi, dan ahli bahasa dengan menggunakan instrumen kuesioner untuk mengetahui kelayakan media e-komik. Setelah dilakukan uji validasi oleh ahli, dilanjutkan dengan memberikan instrumen kuesioner kepada guru fisika, d) Revisi produk yang dihasilkan dari revisi produk adalah produk yang sesuai dengan saran dan penilaian validator.

Tahap implementasi (Implement), produk e-komik diujicobakan kepada peserta didik SMA N 77 Jakarta kelas XI MIA 1 yang berjumlah 36 siswa. Sebelum diberikan media e-komik, peserta didik terlebih dahulu diberikan pre-test. Kemudian setelah itu diberikan media ekomik kepada peserta didik dengan mendownload aplikasi dari Google Playstore dan menginstall aplikasi e-komik pada handphone. Setelah membaca dan menggunakan media e-komik, peserta didik diberikan post-test yang dilakukan pada pertemuan selanjutnya. Selain itu peserta didik juga diberikan instrumen kuesioner setelah mengerjakan soal post-test untuk mengetahui tanggapan peserta didik terhadap media e-komik yang dikembangkan.

Tahap evaluasi (Evaluate) dilakukan revisi apabila dalam implementasi produk masih terdapat kekurangan yang harus diperbaiki, sehingga media e-komik yang dikembangkan bisa digunakan oleh peserta didik dengan mudah dan menjadi media pembelajaran yang dapat mendukung proses pembelajaran.

\section{HASIL DAN PEMBAHASAN}

Produk yang dihasilkan dari penelitian pengembangan ini adalah sebuah media pembelajaran berupa komik elektronik (ekomik) yang berjudul "Dinar in Wonderland" untuk materi fisika SMA kelas XI semester 1 khususnya pada materi dinamika rotasi. Komik elektronik ini berekstensikan .apk dan dapat didownload dari google playstore, adapun link mengunduhnya yaitu http://play.google.com/store/apps/details?id=com.renofinsa.hennyapp. Dengan adanya e-komik ini diharapkan peserta didik lebih antusias belajar fisika karena dilakukan dengan cara yang menarik dan tidak monoton. Adapun tampilan e-komik, yaitu: 


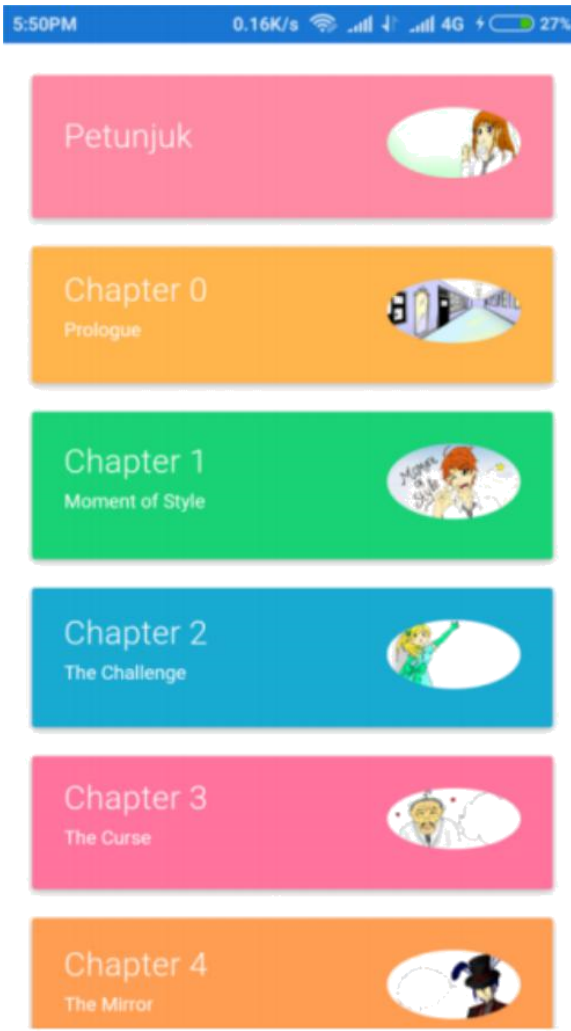

(a)

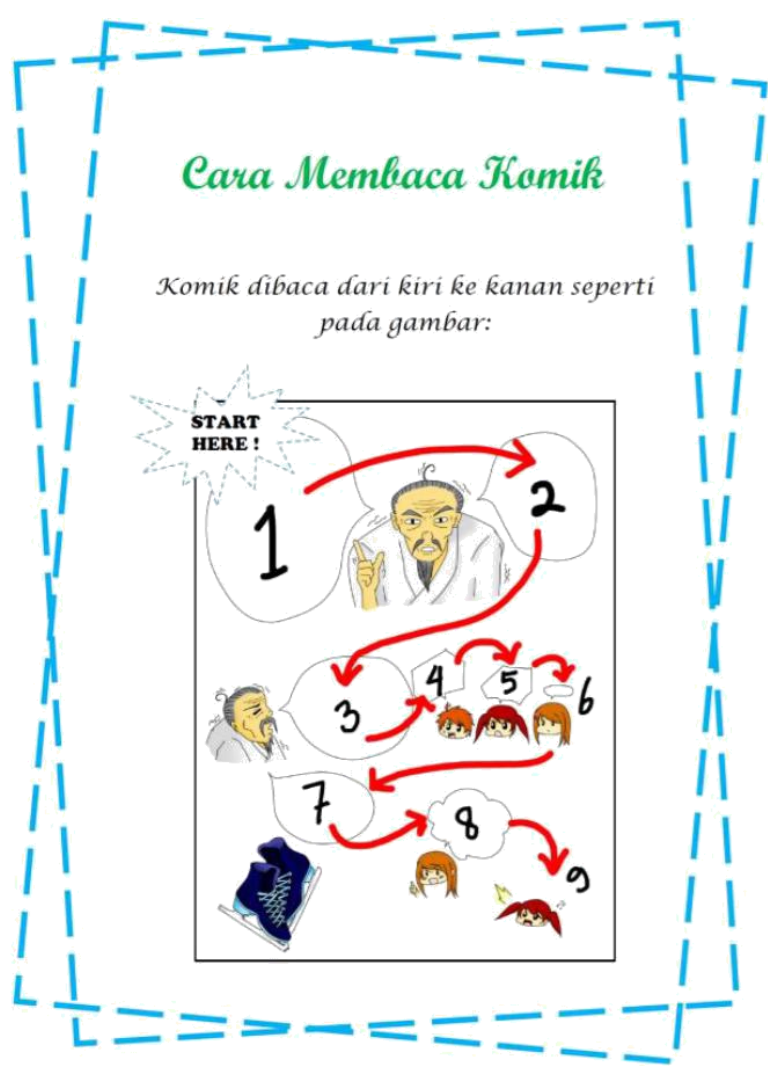

(b)

GAMBAR 1. Tampilan (a) Menu Awal E-Komik (b) Menu Petunjuk

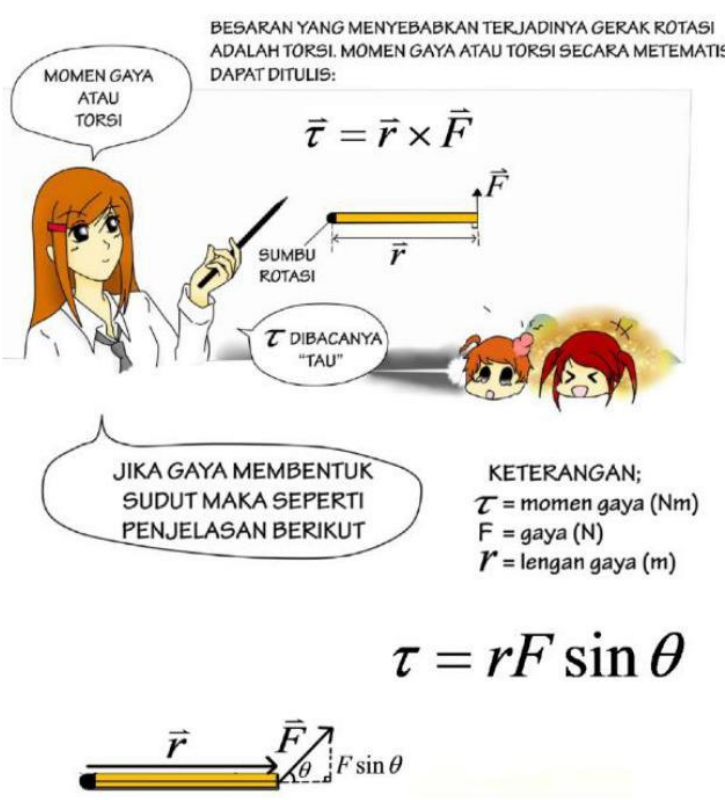

APABILA,

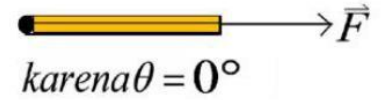

(a)
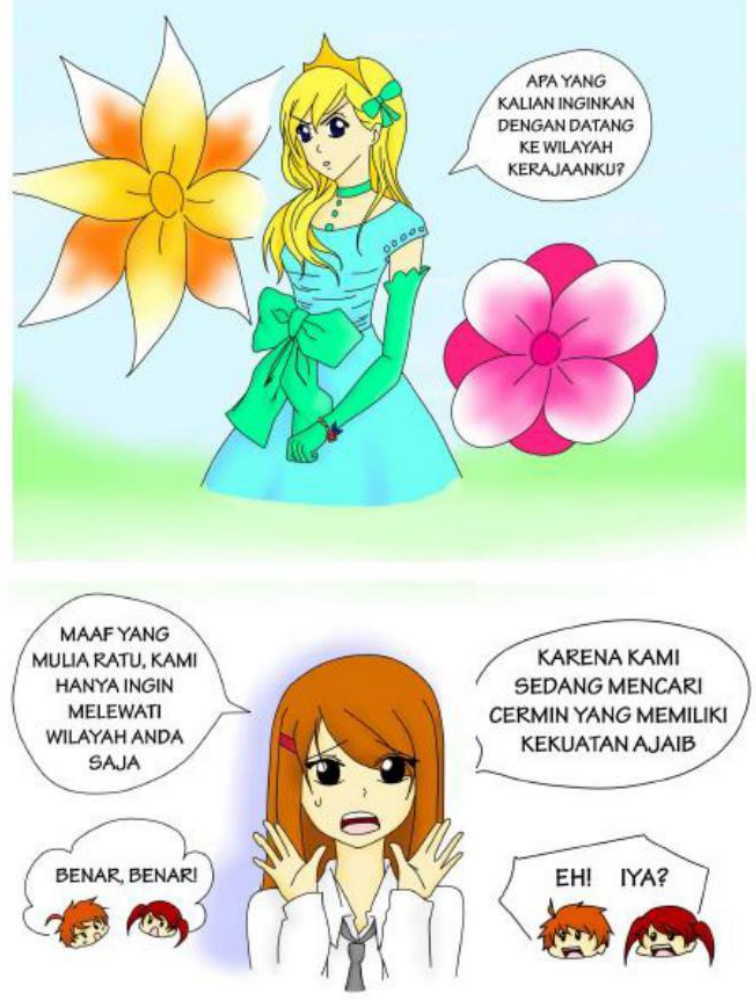

(b)

GAMBAR 2. (a)Tampilan Menu Chapter 1 (b)Tampilan Menu Chapter 2 


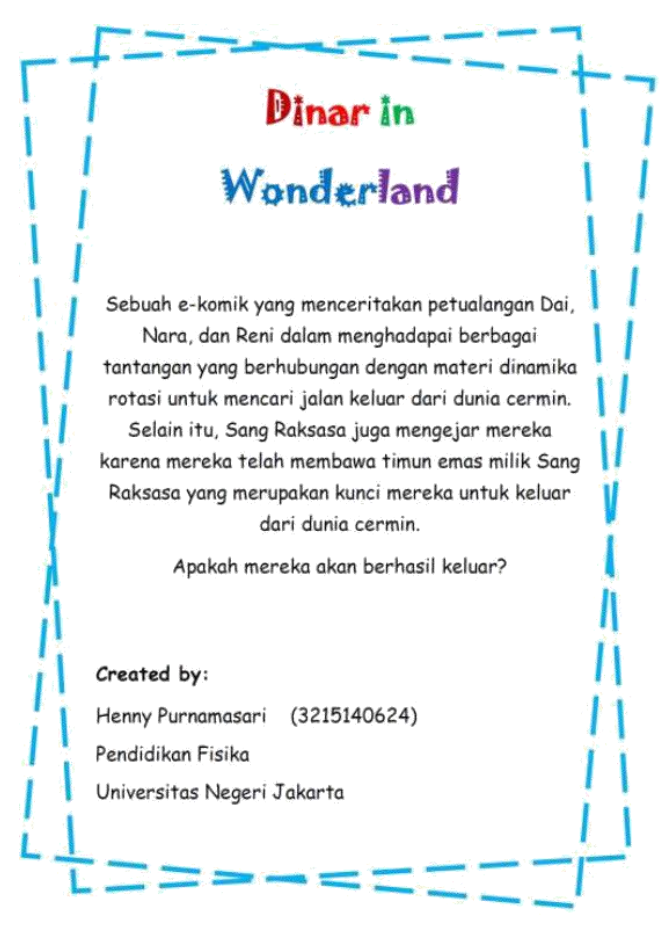

(a)

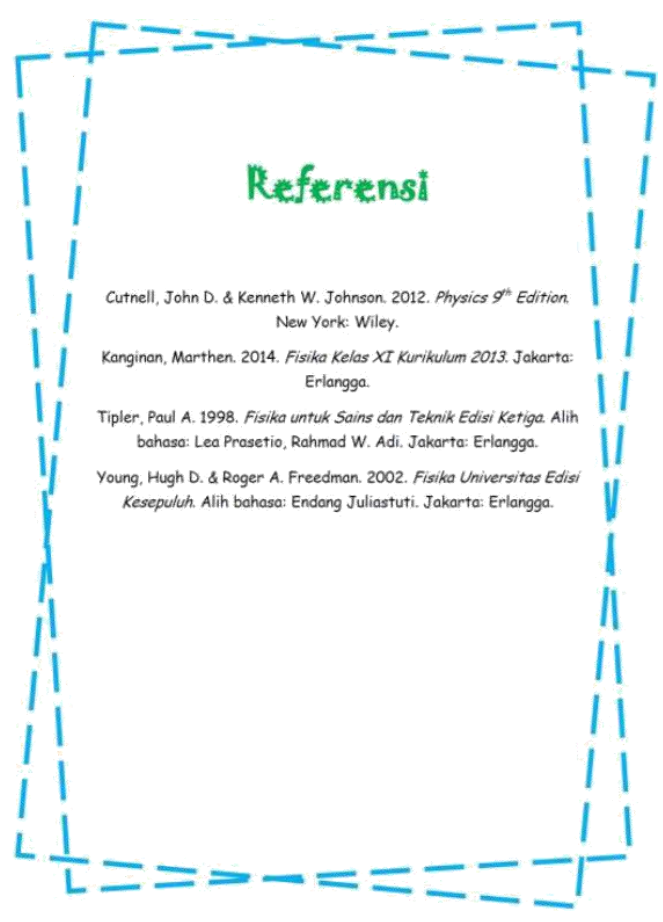

(b)

GAMBAR 3. Tampilan (a) Menu About Us (b) Menu Referensi

Hasil dari uji kelayakan materi didapatkan persentase rata-rata dari seluruh aspek menunjukkan bahwa e-komik yang dikembangkan termasuk dalam interpretasi sangat layak yaitu $83.00 \%$. Hal itu dikarenakan dari hasil validasi pada aspek penyajian dan isi materi komik yang disajikan sudah sesuai dengan peneraparan pada kehidupan sehari-hari dan konten/isi ilustrasi sesuai dengan materi fisika yang terkait. Adapun terdapat saran yang diberikan oleh ahli materi yaitu pada aspek penyajian dalam indikator penyajian ilustrasi.

TABEL 1. Hasil Uji Validasi oleh Ahli Materi

\begin{tabular}{lcl}
\hline \multicolumn{1}{c}{ Aspek yang Diuji } & Persentase & Interpretasi \\
\hline Isi/konten Materi & $84.00 \%$ & Sangat layak \\
\hline Penyajian & $85.00 \%$ & Sangat layak \\
\hline Kebahasaan & $80.00 \%$ & Sangat layak \\
\hline Rata-rata & $83.00 \%$ & Sangat layak \\
\hline
\end{tabular}

Hasil dari uji validasi oleh ahli media didapatkan hasil persentase rata-rata dari seluruh aspek menunjukkan bahwa e-komik yang dikembangkan termasuk dalam interpretasi sangat layak yaitu $78.11 \%$. Hal tersebut dikarenakan pada aspek grafika e-komik pewarnaan gambar komik sudah sesuai dan menarik, komposisi warna aplikasi sesuai dan desain tampilan e-komik sudah sederhana dan menarik. Adapun terdapat saran yang diberikan oleh ahli materi yaitu pada aspek aspek grafika ekomik yaitu pada indikator kesesuaian penggunaan jenis huruf dan ukuran huruf dan pada indikator ketepatan tataletak teks dan gambar.

TABEL 2. Hasil Uji Validasi oleh Ahli Media

\begin{tabular}{lcc}
\hline \multicolumn{1}{c}{ Aspek yang Diuji } & Persentase & Interpretasi \\
\hline Anatomi E-komik & $73.33 \%$ & Layak \\
Grafika E-komik & $81.00 \%$ & Sangat layak \\
Kebahasaan & $80.00 \%$ & Sangat layak \\
Rata-rata & $78.11 \%$ & Sangat layak \\
\hline
\end{tabular}


Hasil dari uji validasi oleh ahli bahasa didapatkan hasil persentase rata-rata dari seluruh aspek menunjukkan bahwa e-komik yang dikembangkan termasuk dalam interpretasi sangat layak yaitu $82.22 \%$. Hal tersebut dikarenakan pada aspek kebahasaan, penggunaan kalimat pada cerita komik mudah untuk dipahami dan penggunaan gaya bahasa sudah baik dan menarik.

TABEL 3. Hasil Uji Validasi oleh Ahli Bahasa

\begin{tabular}{lcc}
\hline \multicolumn{1}{c}{ Aspek yang Diuji } & Persentase & Interpretasi \\
\hline Isi/konten Materi & $80.00 \%$ & Sangat layak \\
Penyajian & $73.33 \%$ & Layak \\
Kebahasaan & $93.33 \%$ & Sangat layak \\
Rata-rata & $82.22 \%$ & Sangat layak \\
\hline
\end{tabular}

Kemudian uji oleh 3 orang guru fisika SMA didapatkan hasil persentase rata-rata dari seluruh aspek penilaian menunjukkan bahwa e-komik yang dikembangkan termasuk dalam interpretasi sangat layak yaitu $86.18 \%$. Hal itu dikarenakan materi yang disajikan udah sesuai dengan kompetensi dasar, materi sudah 76 sesuai dengan indikator pembelajaran, dan materi yang disajikan sudah sesuai dengan kehidupan sehari-hari.

TABEL 4. Hasil Uji Validasi oleh Guru Fisika SMA

\begin{tabular}{lcl}
\hline \multicolumn{1}{c}{ Aspek yang Diuji } & Persentase & Interpretasi \\
\hline Isi/konten Materi & $91.67 \%$ & Sangat layak \\
Penyajian & $82.22 \%$ & Sangat layak \\
Grafika E-komik & $84.17 \%$ & Sangat layak \\
Kebahasaan & $86.67 \%$ & Sangat layak \\
Rata-rata & $86.18 \%$ & Sangat layak \\
\hline
\end{tabular}

Selanjutnya uji coba lapangan yang diberikan kepada 36 siswa SMA kelas XI IPA. Hasil skor gain yang diperoleh dari nilai rata-rata pre-test dan post-test sebesar 0.40 yang menunjukkan bahwa terdapat peningkatan pemahaman peserta didik yang termasuk dalam interpretasi sedang.

\begin{tabular}{lcc}
\multicolumn{3}{c}{ TABEL 5. Hasil Uji Gain } \\
\hline \multicolumn{1}{c}{ Bentuk Test } & Nilai Rata-rata & Nilai Gain \\
\hline Pre-test & 33.89 & 0.40 \\
Post-test & 60.42 & \\
\hline
\end{tabular}

Dari hasil uji lapangan oleh peserta didik SMA didapatkan hasil persentase rata-rata yang menunjukkan bahwa e-komik yang dikembangkan termasuk dalam interpretasi sangat layak yaitu $83.96 \%$. Hal tersebut dikarenakan permasalahan yang disajikan dalam komik sesuai dengan konsep fisika, konten ilustrasi sesuai dengan materi fisika, dan penggunaan bahasa mudah untuk dipahami serta persamaan matematis yang disajikan sudah dilengkapi dengan keterangan lambang atau simbol yang digunakan.

TABEL 4. Hasil Uji Validasi oleh Guru Fisika SMA

\begin{tabular}{lcl}
\hline \multicolumn{1}{c}{ Aspek yang Diuji } & Persentase & Interpretasi \\
\hline Grafika E-komik & $82.22 \%$ & Sangat layak \\
Isi/konten Materi & $85.56 \%$ & Sangat layak \\
Penyajian & $83.06 \%$ & Sangat layak \\
Kebahasaan & $85.00 \%$ & Sangat Layak \\
& & \\
Rata-rata & $83.96 \%$ & Sangat layak \\
\hline
\end{tabular}




\section{KESIMPULAN}

Berdasarkan hasil uji kelayakan materi, media, dan bahasa, serta uji lapangan oleh guru dan peserta didik SMA, dapat disimpulkan bahwa media e-komik pada materi dinamika rotasi yang dikembangkan telah memenuhi kriteria layak sehingga dapat dijadikan media pembelajaran.

\section{REFERENSI}

[1] Hesti and M. , "Pengembangan Handout Dinamika Rotasi dan Kesetimbangan Benda Tegar Berbasis Kontekstual Kelas XI IPA SMA," Jurnal Inovasi dan Pembelajaran Fisika, vol. 3, no. 2, 2016.

[2] BSNP, "Puspendik," 2015. [Online]. Available: http://www.118.98.234.50/luhn/daya_serap.aspx.

[3] D. K. Rusman, Pembelajaran Berbasis Teknologi Informasi dan Komunikasi, Jakarta: PT Raja Grafindo Persada, 2012.

[4] Acolyte, Lebih Cepat Mahir Menggambar Manga Dengan Pensil, Bandung: Ruang Kata Imprint Kawan Pustaka, 2011.

[5] Eastman, "The Spectacular Teacher-Man: Comics as Primary Text in a Science," Juniata Voices; Huntingdon, vol. 12, pp. 156-165, 2012.

[6] L. Susiani, Bikin Komik dengan Adobe Illustrator \& Adobe Photoshop, Yogyakarta: CV Andi Offset, 2006.

[7] I. Kusmayadi and dkk, Be Smart Bahasa Indonesia, Bandung: Grafindo Media Pratama, 2008.

[8] K. Hamidon, M. TS and L. H, "Teachers' Perception towards Usage of Cartoon in Teaching and Learning Physics," Procedia - Social and Behavioral Sciences 7(C), pp. 538-545, 2010.

[9] I. Listiyani and A. Widayati, "Pengembangan Komik Sebagai Media Pembelajaran Akutansi pada Kompetensi Dasar Persamaan Dasar Akutansi untuk Siswa SMA Kelas XI," Jurnal Pendidikan Akutansi Indonesia, vol. 10, no. 2, pp. 80-94, 2012.

[10] S. Prawiradilaga and dkk, Mozaik Teknologi Pendidikan: E-Learning, Jakarta: Prenamedia Group, 2013.

[11] F. Bakri, R. Rasyid, and R. D. A. Mulyaningsih, "Pengembangan Modul Fisika Berbasis Visual untuk Sekolah Menengah Atas (SMA)”, jpppf, vol. 1, no. 2, pp. 67 - 74, Dec. 2015.

[12] H. Kurniawati, D. Desnita, S. Siswoyo, "Pengembangan Media Pembelajaran Berbasis 3D PageFlip Fisika untuk Materi Getaran dan Gelombang Bunyi”, jpppf, vol. 2, no. 1, pp. 97-102, 2016.

[13] I. A. Putri, S. Siswoyo, W. Indrasari, "Pengembangan Media Pembelajaran Fisika Menggunakan Lectora Inspire pada Materi Usaha dan Energi SMA", jpppf, vol. 2, no. 2, pp. 71-78, 2016.

[14] S. Kalatting, V. Serevina, and I. M. Astra, "Pengembangan Media Pembelajaran Fisika Berbasis Web Menggunakan Pendekatan Guided Discovery Learning", jpppf, vol. 1, no. 1, pp. 1 - 8, 2015.

[15] I. M. Astra and U. R. Fitri, "Integrated Lecture Tools to Improve Student Competencies to Develop Physical Learning Media Design”, jpppf, vol. 3, no. 1, pp. 79 - 88, 2017.

[16] S. Rezeki and I. Ishafit, "Pengembangan Media Pembelajaran Interaktif untuk Sekolah Menengah Atas Kelas XI pada Pokok Bahasan Momentum”, jpppf, vol. 3, no. 1, pp. 29-34, 2017.

[17] F. Bakri, B. Z. Siahaan, and A. H. Permana, "Rancangan Website Pembelajaran Terintegrasi dengan Modul Digital Fisika Menggunakan 3D PageFlip Professional", jpppf, vol. 2, no. 2, pp. 113 - 118, 2016.

[18] S. Sarinah, D. Muliyati, and I. M. Astra, "Merancang Komik Cerita Tokoh Menggunakan Aplikasi Comicker sebagai Media Pembelajaran”, jpppf, vol. 2, no. 1, pp. 103 - 110, 2016.

[19] F. Savila, I. M. Astra, and D. Muliyati, "Pengembangan Komik Biografi Sir Isaac Newton Sebagai Media Pembelajaran Fisika Menggunakan Aplikasi Paint Tool SAI." Gravity: Jurnal Ilmiah Penelitian dan Pembelajaran Fisika, vol.4, no.2, 2018.

[20] D. Muliyati, S. Siswoyo, D. Rahmadini, "Komik efek fotolistrik : komik sejarah efek fotolistrik dari 5 ilmuwan." CV Green Circle Digital, 2017.

[21] V. Serevina and D. Muliyati, "Peningkatan Hasil Belajar Siswa pada Materi Dinamika Gerak Partikel Dengan Menerapkan Model Pembelajaran Project Based Learning”, jpppf, vol. 1, no. 1, pp. $61-68,2015$.

[22] S. S. Development, "Paint Tool SAI," 2018. [Online]. Available: http://www.systemax.jp/en/sai. [Accessed 31 July 2018]. 